\title{
Effect of endurance exercise on sweat constituents of athletic Iraqi Arabian horses
}

\author{
B.J. Mohamed \\ Department of Public Health, College of Veterinary Medicine, University of Al- Qadisiyah, Al- Qadisiyah, Iraq \\ Email: Basima.jasim@qu.edu.iq
}

(Received May 8, 2017; Accepted August 30, 2017)

\begin{abstract}
It is well known that Iraq has dry hot weather, especially during summer, so horses sports competitions are stopped. The aims of our research were to study the effect of endurance exercise on sweat constituents of Iraqi Arabian horses. The results show that, after trot, the body temperature was $37.600 \pm 0.058$, the heart rate was $45.875 \pm 0.819$, and the respiration rate was $35.750 \pm 0.708$. After canter, the body temperature was $38.512 \pm 0.058$, the heart rate was $76.000 \pm 0.819$ and the respiration rate was $49.250 \pm 0.708$. After gallop, the body temperature was $39.512 \pm 0.058$, the heart rate was $99.875 \pm 0.819$, and the respiration rate was $60.875 \pm 0.708$. All mean values were significantly different at $\mathrm{P} \leq 0.01$. The mean of body weight was $460.5 \mathrm{~kg}$. The total body surface mean was $396.1 \mathrm{Cm}^{2}$. The mean values of albumin, globulin, $\mathrm{Na}^{+}, \mathrm{K}^{+}, \mathrm{Cl}^{-}, \mathrm{Ca}^{++}, \mathrm{Mg}^{++}, \mathrm{Fe}^{++}, \mathrm{Cu}^{++}$, and $\mathrm{Zn}^{+}$, in trot were $3.512 \pm 0.089,3.875 \pm 0.725,3.637 \pm 0.072,2.062 \pm 0.086,5.962 \pm 0.141,0.167 \pm 0.006,0.987 \pm 0.007,4.875 \pm 0.700$, $0.712 \pm 0.515,11.750 \pm 0.422$ and $0.180 \pm 0.002$, respectively, while the results in canter were $3.925 \pm 0.086,4.750 \pm 0.111$, $4.787 \pm 0.104, \quad 3.637 \pm 0.285, \quad 6.637 \pm 0.090, \quad 1.487 \pm 0.953, \quad 0.161 \pm 0.008, \quad 5.537 \pm 0.105, \quad 0.987 \pm 0.666, \quad 12.262 \pm 0.106$ and $0.236 \pm 0.007$, respectively. In gallop were $5.612 \pm 0.107,6.012 \pm 0.158,6.675 \pm 0.144,5.062 \pm 0.138,7.550 \pm 0.090,2.750 \pm 0.122$, $0.256 \pm 0.009,6.400 \pm 0.070,1.600 \pm 0.845,12.650 \pm 0.073$ and $0.276 \pm 0.004$, respectively. Our results indicate clearly a high loss of essential proteins and minerals during sweating which must be compensated by food additives specially during summer, to prevent many healthy problems so we believe that ratios of these proteins and minerals must be calculated according to many factors like, weather climate, the type of the horse jobs (jump, polo, races, show,.....etc.) and the body weights and ages.
\end{abstract}

Keywords: Endurance, Exercise, Sweat, Constituents, Iraqi, Horses.

Available online at http://www.vetmedmosul.org/ijvs

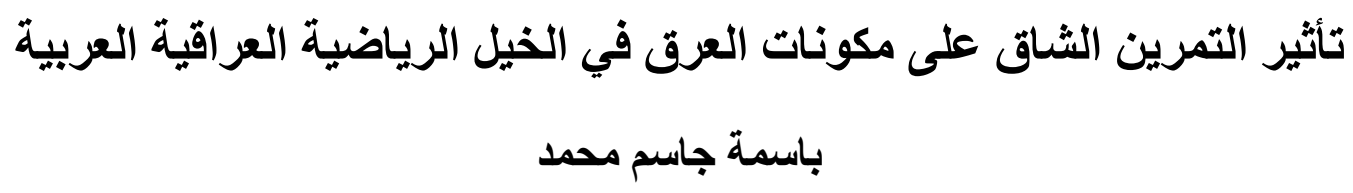

قسم الصحة العامة، كلية الطب البيطري، جامعة القادسية، القادسية، العراق

من المعروف ان طقس العراق يتميز بكونه طقس حار جاف خصوصاً في فصل الصيف، وهذا يؤدي الى توقف مسابقات الخيول

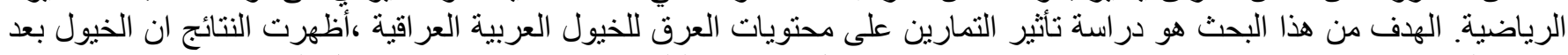

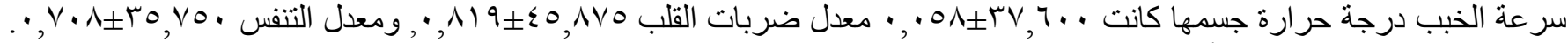

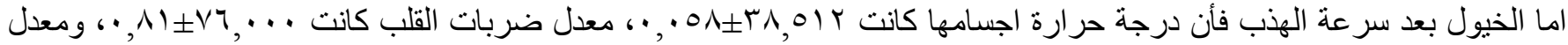

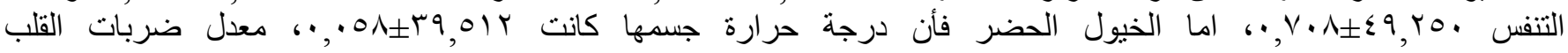
ه

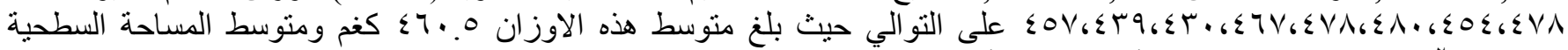

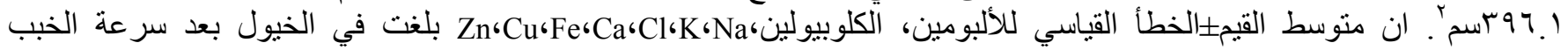




\section{Introduction}

It is well known that, Iraq has a dry hot weather specially during summer, so the horse sports competitions are stopped. Iraqi Arabian horses have the capacity to carry on the external influences by adaptation. It is well known that, horses have capable of maintaining their internal body temperature relatively constant because they are homoeothermic animals. This feature is achieved by activating thermo- regulatory mechanism. The physiological mechanisms like sweating, respiratory rate, skin blood flow, and changes in heart rate play essential especial roles $(1,2)$.

The horses ability is the key factor to recognize the condition as a trigger for all the physiological processes, this we can called «stress response» but the hypothalamus - pituitary - adrenal axis is regarded the real regulating system in the background of these processes (3). The exercise is just a such stressor, it is responsible of energy mobilization, enforce blood circulation, and maintain the constant body temperature which require sensors in the regulatory system, to formulate the exact response which lead to sweat production (3). The autonomic nervous system is responsible of maintaining the body temperature by regulating the sweat production (4). During sport competitions the veterinarian evaluate at checkpoints, the hydration of the horses by heart rate measurement, in addition to evaluate many subjective parameters like the mucous membranes color and refill time measurements, persistence of a skin tent, jugular vein fill time measurements, and the intestinal motility auscultation. With the measurement of the body mass changes in working horses, unfortunately, there are no well comparison of these measurements $(5,6)$.

For thermoregulatory cooling of the horse body, and during the exercise the cardiac output also increase in response to demands of increased skin flow, and as well as the demands of the metabolic demands of active skeletal muscles (7).The horses can consumed the electrolytes in the feed, and lost them by three ways, sweat, feces, and urine. In contrast, sodium intake is more variable and can be marginal, investigations of electrolytes balance has revealed that most horses eating predominantly forage ingest excess potassium and chloride (8). $10 \mathrm{gm} /$ day is calculated as the maintenance requirement for $\mathrm{Na}+$ for a sedentary $500 \mathrm{~kg}$. horse weight (9) or provide by $\sim 25 \mathrm{gm}$ of sodium chloride/day. The horses that are being supplemented with sodium chloride, the adequacy of dietary sodium is most practically estimated by measurement of urine sodium concentration, urine sodium can be $<10 \mathrm{mmol} / \mathrm{L}$ in those horses with a marginal sodium diet urine sodium should be collected from resting horses because urine sodium can be affected by exercise (10). Within narrow ranges, the maintain body ions contents may be matched appropriately the daily intake and output of electrolytes. The balance is greatest for sodium, potassium and chloride ions that provided the osmotic skeleton of all the body fluids. More than $90 \%$ of exchangeable sodium and chloride is contained within the extracellular fluid component so further the $\mathrm{Na}+, \mathrm{K}+$, and $\mathrm{Cl}^{-}$are not evenly distributed throughout the total body weight, while more than $98 \%$ of potassium is contained within the intracellular fluid constituents (11).

According to our knowledge, there is no any previous study in our Iraqi horses, we design this research to study the effects of endurance exercise on sweat constituents of Iraqi Arabian horses.

\section{Materials and methods}

\section{Experimental animals}

At May $\left(35^{\circ} \mathrm{C}\right), 8$ athletic Iraqi Arabian horses that were housed in a private stable, sporadic stall for each one in Al- Najaf province were used. Their ages range 36-42 months, with calculated body weights range $430-480 \mathrm{kgs}$. Which were estimated according to (12) by dividing chest girth, $\left(\mathrm{Cm}^{2}\right) \mathrm{x}$ body length, $(\mathrm{Cm}$.) on 11.9. The total body surfaces were estimated according to Meeh's formula (13) Body surface $(\mathrm{S})=$ Meeh's constant $(\mathrm{K}) \mathrm{x}$ Body weight ${ }^{0.6}$. They had exercised daily with many different speeds. The horses were under veterinarian routine check regularly. They also were subjected to preventive deworming treatments, feed was balanced in terms of energy, proteins, vitamins, and minerals considering the specific 
requirements connected with standards of animal feeding. The main feed were grains, alfalfa hay, straw, mineral blocks with ad libitum clean water.

Table 1: Distribution of age, sex, and color of the 8 Iraqi Arabian horses included in the study

\begin{tabular}{cccc}
\hline N & Age (months) & Sex & color \\
\hline 1 & 40 & Mare & White \\
2 & 38 & Stallion & Red \\
3 & 36 & Mare & Brown \\
4 & 39 & Stallion & Brown \\
5 & 40 & Stallion & Red \\
6 & 42 & Stallion & Black \\
7 & 39 & Mare & White \\
8 & 41 & Stallion & Black \\
\hline
\end{tabular}

\section{Sample collection}

The athletic horses were washed with shampoo, clean water and dried with clean towels before and after running, which were (24) hours interval. The body temperatures, respiration rates and heart beats were recorded before and after each type of run. The horses ran at trot $(20 \mathrm{~km} / \mathrm{h})$, canter $(30 \mathrm{~km} / \mathrm{h})$ and gallop $(60 \mathrm{~km} / \mathrm{h})$ for $(5 \mathrm{~km})$ distance, the speed is calculated by using sports clock. The sweat samples, were collected from those, that formed at the animals neck and chest, a dirty brown fluid were collected directly after each speed by special curate in sterile containers, send to laboratory in ice box. The samples were filtrated to exclude dust, hair, sand particles then centrifuged at $5000 \mathrm{rpm}$ for $10 \mathrm{~min}$. Then sulphosalicylic acid was added to the highly turbid supernatant. The supernatant was analyzed by spectrophotometer (Chrom Tech, V-1100 spectrophotometer MED \&Lab Instrument, USA). using commercial special kits for albumin and globulin, $\mathrm{Na}^{+}, \mathrm{K}^{+}, \mathrm{Cl}^{-}, \mathrm{Ca}^{++}, \mathrm{Mg}^{++}, \mathrm{Fe}^{+}, \mathrm{Cu}++, \mathrm{Zn}^{+}$, and $\mathrm{Mn}^{+}$.

\section{Statistical analysis}

The results are expressed as mean \pm SE. Statistical analysis was carried out using SPSS version 11 for Windows (IBM, Armonk, NY, USA). Group differences were analyzed by one and two-way analysis of variance (ANOVA), followed by Least significant differences; P < 0.01 was considered significant (14).

\section{Results}

Table 2 shows the mean values \pm standard errors of the body temperature $\left(\mathrm{C}^{\circ}\right)$, the heart rates (beats/min.), and the respiration rates (breath $/ \mathrm{min}$.) before and after each running speed. Before trot, the body temperatures are (37.437 \pm 0.058$)$, the heart rates are $(34.000 \pm 0.819)$, and the respiration rates are $(15.250 \pm 0.708)$, while after trot, the body temperatures are $(37.600 \pm 0.058)$, the heart rates are $(45.875 \pm 0.819)$, and the respiration rates are $(35.750 \pm 0.708)$. Before canter, the body temperatures are (37.437 \pm 0.058$)$, the heart rates are $(34.750 \pm 0.819)$, and the respiration rates are $(15.750 \pm 0.708)$, while after canter, the body temperatures are $(38.512 \pm 0.058)$, the heart rates are $(76.000 \pm 0.819)$, and the respiration rates are (49.250 \pm 0.708$)$. Before gallop, the body temperatures are $(37.500 \pm 0.058)$, the heart rates are $(35.000 \pm 0.819)$, and the respiration rates are $(15.250 \pm 0.708)$, while after gallop, the body temperatures are $(39.512 \pm 0.058)$, the heart rates are $(99.875 \pm 0.819)$, and the respiration rates are $(60.875 \pm 0.708)$. All the mean values are highly significant at $\leq 0.01$.

Table 3 shows the body weights $(\mathrm{kg})$, the body weight mean value $(\mathrm{kg})$, the total body surfaces $\left(\mathrm{Cm}^{2}\right)$, and the surface mean value $\left(\mathrm{Cm}^{2}\right)$. The body weights are 457,439 , $430,467,478,480,454$ and $478 \mathrm{~kg}$, respectively. The body weight mean value was $460.5 \mathrm{~kg}$. The total body surfaces were $394.4,385.0,380.2,399.5,405.1,406.2,393.8$ and $405.1 \mathrm{Cm}^{2}$, respectively. The total surfaces mean value was $396.1 \mathrm{Cm}^{2}$.

Table 2: $\mathrm{M} \pm \mathrm{SEM}$ of body temperature $\left({ }^{\circ} \mathrm{C}\right)$, heart rate (beats/min.), and respiration rate (breaths/min.), before and after different running speeds

\begin{tabular}{llccc}
\hline \multirow{2}{*}{ Speeds } & Time of collection & \multicolumn{3}{c}{ Parameters } \\
\cline { 3 - 5 } & Before & $\begin{array}{c}\text { Body } \\
\text { Temperature }\left(\mathrm{C}^{\circ}\right)\end{array}$ & $\begin{array}{c}\text { Heart rate } \\
\text { (beats/min.) }\end{array}$ & $\begin{array}{c}\text { Respiration rate } \\
\text { (breaths/min.) }\end{array}$ \\
\hline \multirow{2}{*}{ Trot } & After & $37.437 \pm 0.058$ & $34.000 \pm 0.819$ & $15.250 \pm 0.708$ \\
& Canter & $37.600 \pm 0.058$ & $45.875 \pm 0.819$ & $35.750 \pm 0.708$ \\
& After & $37.437 \pm 0.058$ & $34.750 \pm 0.819$ & $15.750 \pm 0.708$ \\
Gallop & Before & $38.512 \pm 0.058$ & $76.000 \pm 0.819$ & $49.250 \pm 0.708$ \\
LSD $_{0.01}$ & After & $37.500 \pm 0.058$ & $35.000 \pm 0.819$ & $15.250 \pm 0.708$ \\
Sinyyy$^{*}$ & & $39.512 \pm 0.058$ & $99.875 \pm 0.819$ & $60.875 \pm 0.708$ \\
\end{tabular}

Similar letters: mean no significant variations at $\mathrm{P} \leq 0.01$. 
Table 3: shows the body weights $(\mathrm{kg})$, the body weight mean value $(\mathrm{kg})$, the total body surfaces $\left(\mathrm{Cm}^{2}\right)$, and the total body surface mean value $\left(\mathrm{Cm}^{2}\right)$

\begin{tabular}{ccccc}
\hline $\begin{array}{c}\text { No. of } \\
\text { horses }\end{array}$ & $\begin{array}{c}\text { Body } \\
\text { weights } \\
(\mathrm{kg})\end{array}$ & $\begin{array}{c}\text { Body } \\
\text { weights } \\
\text { mean } \\
\text { value } \\
(\mathrm{kg})\end{array}$ & $\begin{array}{c}\text { Total } \\
\text { body } \\
\text { surfaces } \\
\left(\mathrm{Cm}^{2}\right)\end{array}$ & $\begin{array}{c}\text { Total body } \\
\text { surfaces } \\
\text { mean } \\
\text { value }\left(\mathrm{Cm}^{2}\right)\end{array}$ \\
\hline 1 & 457 & & 494.4 & \\
2 & 439 & & 385.0 & \\
3 & 430 & & 380.2 & \\
4 & 467 & 460.5 & 399.5 & 396.1 \\
5 & 478 & & 405.1 & \\
6 & 480 & & 406.2 & \\
7 & 454 & & 393.8 & \\
8 & 478 & & 405.1 & \\
\hline
\end{tabular}

S: Total body surface (TBS), K: Meeh's constant=10, W: Body weight ${ }^{0.6}$

Table 5 shows that the mean values \pm standard errors of albumin, globulin, $\mathrm{Na}, \mathrm{K}, \mathrm{Cl}, \mathrm{Ca}, \mathrm{Mg}, \mathrm{Fe}, \mathrm{Cu}, \mathrm{Zn}, \mathrm{Mg}$ levels in trot were $3.512 \pm 0.089,3.875 \pm 0.725,3.637 \pm 0.072$, $2.062 \pm 0.086, \quad 5.962 \pm 0.141, \quad 0.167 \pm 0.006, \quad 0.987 \pm 0.007$, $4.875 \pm 0.700,0.712 \pm 0.515,11.750 \pm 0.422$ and $0.180 \pm 0.002$, respectively, while in canter they were $3.925 \pm 0.086$,
$4.750 \pm 0.111, \quad 4.787 \pm 0.104, \quad 3.637 \pm 0.285, \quad 6.637 \pm 0.090$, $1.487 \pm 0.953, \quad 0.161 \pm 0.008, \quad 5.537 \pm 0.105, \quad 0.987 \pm 0.666$, $12.262 \pm 0.106$ and $0.236 \pm 0.007$, respectively, and in gallop were $\quad 5.612 \pm 0.107, \quad 6.012 \pm 0.158, \quad 6.675 \pm 0.144$, $5.062 \pm 0.138, \quad 7.550 \pm 0.090, \quad 2.750 \pm 0.122, \quad 0.256 \pm 0.009$, $6.400 \pm 0.070,1.600 \pm 0.845,12.650 \pm 0.073$ and $0.276 \pm 0.004$, respectively.

Table 4: shows the normal values of sweat constituents according to their references

\begin{tabular}{lcc}
\hline Constituents & Values & References \\
\hline Albumin $(\mathrm{g} / \mathrm{l})$ & 2.9 & $(15)$ \\
Globulin $(\mathrm{g} / \mathrm{l})$ & 3.2 & $=$ \\
Sodium $(\mathrm{g} / \mathrm{l})$ & 2.8 & $(16),(17)$ \\
Potassium $(\mathrm{g} / \mathrm{l})$ & 1.4 & $=$ \\
Chloride $(\mathrm{g} / \mathrm{l})$ & 5.3 & $=$ \\
Calcium $(\mathrm{g} / \mathrm{l})$ & 0.12 & $=$ \\
Magnesium $(\mathrm{g} / \mathrm{l})$ & 0.05 & $=$ \\
Iron $(\mathrm{mg} / \mathrm{l})$ & 4.3 & $=$ \\
Copper $(\mathrm{mg} / \mathrm{l})$ & 0.3 & $=$ \\
Zinc $(\mathrm{mg} / \mathrm{l})$ & 11.4 & $=$ \\
Manganese $(\mathrm{mg} / \mathrm{l})$ & 0.16 & $=$ \\
\hline
\end{tabular}

Table 5: $\mathrm{M} \pm \mathrm{SEM}$ of some sweat constituents after different running speeds

\begin{tabular}{|c|c|c|c|c|c|c|c|c|c|c|c|}
\hline \multirow[b]{2}{*}{ Speeds } & \multicolumn{11}{|c|}{ Parameters } \\
\hline & $\begin{array}{l}\text { Albumin } \\
\text { (g/100ml) }\end{array}$ & $\begin{array}{l}\text { Globulin } \\
\text { (g/100ml) }\end{array}$ & $\begin{array}{c}\mathrm{Na} \\
(\mathrm{g} / \mathrm{l})\end{array}$ & $\begin{array}{c}\mathrm{K} \\
(\mathrm{g} / \mathrm{l})\end{array}$ & $\begin{array}{c}\mathrm{Cl} \\
(\mathrm{g} / \mathrm{l})\end{array}$ & $\begin{array}{c}\mathrm{Ca} \\
(\mathrm{g} / \mathrm{l})\end{array}$ & $\begin{array}{c}\mathrm{Mg} \\
(\mathrm{g} / \mathrm{l})\end{array}$ & $\begin{array}{c}\mathrm{Fe} \\
(\mathrm{mg} / \mathrm{l})\end{array}$ & $\begin{array}{c}\mathrm{Cu} \\
(\mathrm{mg} / \mathrm{l})\end{array}$ & $\begin{array}{c}\mathrm{Zn} \\
(\mathrm{mg} / \mathrm{l})\end{array}$ & $\begin{array}{c}\mathrm{Mn} \\
(\mathrm{mg} / \mathrm{l})\end{array}$ \\
\hline \multirow{2}{*}{ Trot } & $3.512 \pm$ & $3.875 \pm$ & $3.637 \pm$ & $2.062 \pm$ & $5.962 \pm$ & $0.167 \pm$ & $0.987 \pm$ & $4.875 \pm$ & $0.712 \pm$ & $11.750 \pm$ & $0.180 \pm$ \\
\hline & 0.089 & 0.725 & 0.072 & 0.086 & 0.141 & 0.006 & 0.007 & 0.700 & 0.515 & 0.422 & 0.002 \\
\hline \multirow{2}{*}{ Canter } & $3.925 \pm$ & $4.750 \pm$ & $4.787 \pm$ & $3.637 \pm$ & $6.637 \pm$ & $1.487 \pm$ & $0.161 \pm$ & $5.537 \pm$ & $0.987 \pm$ & $12.262 \pm$ & $0.236 \pm$ \\
\hline & 0.086 & 0.111 & 0.104 & 0.285 & 0.090 & 0.953 & 0.008 & 0.105 & 0.666 & 0.106 & 0.007 \\
\hline \multirow{2}{*}{ Gallop } & $5.612 \pm$ & $6.012 \pm$ & $6.675 \pm$ & $5.062 \pm$ & $7.550 \pm$ & $2.750 \pm$ & $0.256 \pm$ & $6.400 \pm$ & $1.600 \pm$ & $12.650 \pm$ & $0.276 \pm$ \\
\hline & 0.107 & 0.158 & 0.144 & 0.138 & 0.090 & 0.122 & 0.009 & 0.070 & 0.845 & 0.073 & 0.004 \\
\hline $\operatorname{LSD}_{0.01}$ & 0.287 & 0.362 & 0.335 & 0.575 & 0.334 & 0.271 & 0.033 & 0.253 & 0.209 & 0.237 & 0.010 \\
\hline
\end{tabular}

\section{Discussion}

It is well known that, Iraqi Arabian horses can carry on the hot, humid conditions. Iraq, has long summer (hot weather), begins from June to November, so at this period, the Iraqi sports are stopped. A lot of researchers studied many aspects of Iraqi Arabian horses (19-22). Dehydration is one of the most important health problems of Iraqi sports horses which veterinarians and trainers are deal with.

Sweat is a physiological response to heat stress (exercise, weather, fear, fighting....etc.), under conditions of heat stress, the body stores the heat, resulting in an increase of the circulatory blood temperature. This increase is sensed by the hypothalamus, which is responsible for the thermoregulation response to heat stress through cutaneous vasodilation, increased production of sweat by sweat glands (18). In hoses, in particular, prolonged periods of sweating at high rates results in water and electrolyte losses that can lead to dehydration with ensuing poor performance and clinical signs of heat strain if unchecked (23). Table 2 shows an highly significant variations at $\mathrm{P} \leq 0.01$ of the increase of body temperatures according to the top of exercise (gallop) $60 \mathrm{~km} / \mathrm{h}$., this indicate to high increase of heat storage. These results accompanied with a lot of researchers in their previous studies in many breeds. Our results, indicate that heart beats are highly significantly at 
$\mathrm{P} \leq 0.01$, and the increases are threefold (from 32 to 99 bpm), similarly (24) and (25) found that top athletes bpm increases less than fourfold. We believe that, rise of body temperature may be due to the physiologic effect of the release of adrenaline circulating levels during gallop. During exercise, skeletal muscle contraction generates high heat that could be get rid of convective blood flow throughout the body to the skin for dissipation to the environment since evaporation of sweat provides the greatest cooling effect (26). The high level of heart beats occurs to provide the requirements of blood to the cutaneous dilated vessels. Also, the increase in respiratory rate due to the running speeds may assist in cooling blood circulation which lead to decrease the heat storage and at the same time demand the requirements of more quantities of blood particularly to the cutaneous dilated vessels. Our findings indicate a highly significant variations at $\mathrm{P} \leq 0.01$ of respiratory rate, that may refer to increase of $\mathrm{VO}_{2}$ value during the maximal exercise. It is empirically confirmed that one of the results of intense training of horses is an increase $\mathrm{VO}_{2}$ max by about $25 \%$ (27). Horses may even double the number of erythrocytes circulating in the blood which is translated into facilitating the transport of oxygen in the body $(28,29)$. It is well known that, Iraqi Arabian horses are classified as a light horses. A lot of researchers estimate the total body surfaces of about (30) mammals depending on the calculated body weight by using Meeh's formula. Body weights (metabolic rates) can be influenced by the hot weather. The high total body surface will increase the sweat out put particularly in hot weather as in Iraq, although Arabian breed has adapted genetically among thousands of years on the hot climate, it's worthwhile to mention that no previous research estimate the total body surfaces of our Iraqi Arabian horses, which add a knowledge about dehydration problem and its complications in our Iraqi horses. We find, it's very useful to high light the normal values of some essential sweat constituents as in table 4 to understand clearly the changes of these values according to each running speed which is included in our study. Table 5 shows clearly the highly significant variations at $\mathrm{P} \leq 0.05$ of the proteins and the essential different minerals specially in high speed (gallop). These results are accompanied with a lot of studies in different breeds of horses $(24-26,30)$. Our results indicate clearly to the high lost of these essential proteins and minerals during sweating which must be compensated by food additives specially during summer, to prevent many healthy problems so we believe that ratios of these proteins and minerals must be calculated according to many factors like, weather climate, the type of the horse jobs (jump, polo, races, show,.....etc.), the body weights and ages. We hope that our study may open the door for more future studies in Iraq to design the standard feeding ratios according the previous factors.

\section{References}

1. Jodkowsks E, Dudek K, Przewozny M. The maximum temperatures $\left(\mathrm{T}_{\max }\right)$ distribution on the body surface of sport horses. J Life Sci. 2011;5:291-297.

2. McKeever KH, Eaton TL, Geiser S, Kearns CF, Lehnhard RA. Age related decreases. I. Thermoregulation and cardiovascular function in horses. Equine Vet J. 2010;42:449-454.

3. Coenen M. Exercise and stress: impact on adaptive processes involving water and electrolytes. Live produ Sci. 2005;92:131-145.

4. Grosman B, Shaik OS, Helwig BG, Leon LR, Doyle III FJ. Aphysiological systems approach to modeling and resetting of mouse thermoregulation under heat stress. J Appl Physiol. 2011;111:938945.

5. Schott, H C, Marlin DJ, Geor R J, Holbrook TC, Deaton CM, Vincent T, Dacre K, Schroter RC, JoseCunilleras E, Cornelisse CJ. Changes in selected physiological and laboratory parameters in elite horses competing in a $160 \mathrm{~km}$ endurance race. Equine Vet J. 2006;Suppl.36:37-42.

6. Pritchard JC. Burn CC, Barr ARS, Whay HR. Validity of indicators of dehydration in working horses: a longitudinal study of changes in skin tent duration, mucous membrane dryness and drinking behavior. Equine Vet J. 2008;40:558-564.

7. Rowell LB. Human circulation regulation during physical stress. New York: Oxford University Press. 1986;pp:363-406.

8. Groenendyk S, English PB, Abetz I. External balance of water and electrolytes in the horse. Equine Vet J. 1988;20:189-193.

9. Anon SIS. National Research Council Nutrient Requirements of Horses, $6^{\text {th }}$ ed., National Academy Press, Washington DC. 2007.

10. Schott HC, Bayly WM, Hodgson DR. Urinary excretory responses in exercising horses: effects on fractional excretion values. In Proc. 11th Annu. Meet. Assoc. Equ Sports Med. 1992;11:23-29.

11. Schott HC. Hinchcliff KW. Fluids, electrolytes, and bicarbonate. Vet Clin North Amer Equine Pract. 1993;9:577-604.

12. Hall LW. Wright's veterinary anaesthesia and analgesia. London: BaillièreTindall; 1971;176.

13. DuBois EL. Basal metabolism in health and disease ( $3^{\text {rd }}$ ed). Philadelphia: Lea \& Febiger, 1936;pp: 142.

14. SPSS. User guid: statistics, version q.o.l. spss Inc. Chicago.IL. 1999.

15. Jirka M, Kotas J. Some observations of the chemical combination of horse sweat. J Physiol. 1959;147:74-77.

16. Meyer H, Heilemann M, Hipp-Quarton A, Perez-Noriega H. Amount and composition of sweat in ponies. Adv Anim Physiol Anim Nutr. 1990b;21,21-34.

17. McCutcheon LJ, Geor RJ. Sweating fluid and ion losses and replacement. Vet Clin North Am Equine Pract. 1998;14(1):75-95. Review.

18. Glesson M. Temperature regulation during exercise. Int J Sports Med. 1998;19 Suppl.2:S96-9.

19. Towfik AI. The effect of running at many speeds on some synovial fluid constituents in Iraqi Arabian horses. AL-Qadisiya J Vet Med Sci. 2015;14(1):39-43.

20. Towfik AI, Hamza AS, Munahi AK. The effect of Henna (Lawsonia inermis) on the wound healing of local Arabian horses. J Kerbala Uni. 2015;13(1):78-91.

21. AL-Khauzai AL, Towfik AI, Hamza AS. Study the effect of some factors on the conformation of Iraqi Arabian horses. Kufa J Vet Med Sci. 2014;5(1):85-97.

22. Towfik AI, Abdul-Shaheed HG, Munahi AK, Kadhim SS. Effect of iron injections and exercise on some blood parameters and wound bleeding in Iraqi Arabian horses. Kufa J Vet Med Sci. 2016;7(2):204210.

23. Maughan RJ, Lindinger MI. Preparing for and competing in the heat. Equine Vet J. 1995:Suppl.20:8-15.

24. Lindinger MI. Sweating, dehydration and electrolyte supplementation: Challenges for the performance horse. Proceeding 
of the 4th European Eq. Nutrition \& Health Congress. Netherlands. 2008;18-19. The (p.46-56).

25. Butler PJ, Woakes AJ, Smale K, Robert CA, Hillidge CJ, Snow DH, Marlin DJ. Respiratory and cardiovascular adjustment during exercise of increasing intensity and during recovery in Thoroughbred racehorses. J Exp Biol. 1993;179:159-180.

26. Kobluk CN, Gross GM. Exercise intolerance and poor performance in western performance and sprint horses. Vet Clin North Am Equine Pract. 1996;12:581-606.

27. Evans DL, Rose RJ. Cardiovascular and respiratory responses in thoroughbred horses during treadmill exercise. J Exp Biol. $1988 ; 134: 397-408$
28. Hinchcliff KW, Geor RJ, Kaneps AJ. Equine exercise. The science of exercise in the athletic horse. Saunders W.B. Elsevier, Edinburgh, London, New York, Oxford, Philadelphia, St. Louis, Sydney, Toronto. 2008.

29. Kunugiyama I, Ito N, Narizuka M. Measurement of erythrocyte volumes in splenectomized horses and sham- operated horses at rest and during maximal exercise. J Vet Med Sci. 1997;59:733-737.

30. Al- Nawaisheh A, Bataynefh M, Al- Nawayseh A, Alsuod H. Physiological responses of distance runners during normal and warm conditions. J Exer Physiol. 2013;16(2):1-11. 